\title{
Sub-Saharan African Countries' Dependence on the External Inflation: Empirical Evidence Using Copulas
}

\author{
Bruno Ferreira Frascaroli ${ }^{1}$, Jailson da Conceição Teixeira de Oliveira ${ }^{2}$ \\ ${ }^{1}$ Graduate Program of Economics (PPGE), Federal University of Paraíba (UFPB), Brazil \\ ${ }^{2}$ Ministry of Finance, Superior Institute of Social Science and Laws, Cape Verde \\ Correspondence: Bruno Ferreira Frascaroli, Graduate Program of Economics (PPGE), Federal University of \\ Paraíba (UFPB), Brazil.
}

Received: September 19, 2017

Accepted: October 16, $2017 \quad$ Online Published: October 27, 2017

doi:10.5539/ibr.v10n12p1

URL: https://doi.org/10.5539/ibr.v10n12p1

\begin{abstract}
The purpose of this study is to estimate the dependence between the inflation, given by the Consumer Price Index (CPI), in part of the Sub-Saharan African (SSA) countries with the CPI observed in the Euro Monetary Zone (EMZ) countries. To achieve this goal, we adopted the empirical methodology of Copulas, which was used in the analysis of the CPI, in bivariate models context. The results were controlled by the countries which adopted fixed and flexible exchange rate regimes. They suggest that the CPI in the sampled countries which adopted fixedexchange rate regimes, as Sao Tome and Principe, Benin, the countries of the West African Economic and the Monetary Union (WAEMU), Burkina Faso, Ivory Coast and Togo had more significant dependence relationship with the Euro. On the other hand, the countries which adopted flexible exchange rate regimes as Cape Verde, Burkina Faso, Guinea-Bissau, Mali, Senegal and Togo presented dependence on upper tail of the distribution, i.e., for the periods of increasing in the CPI. Maybe, it means that those countries had inelastic demands for tradable goods coming from the EMZ countries. We conclude that the imported inflation is an important issue to be considered by the policy makers of developing countries such as the studied, mainly for those which adopted fixed regimes, eventually change to flexible exchange regimes.
\end{abstract}

Keywords: inflation, dependence, Sub-Saharan African countries, European Monetary Zone, Copulas

\section{Introduction}

With the financial liberalization and the increasing integration among countries and economical blocs, the financial crises that occurred in the last decades, characterized by strong production decreases, consumption, and capital flows, increased. This has generated, specially from economically fragile countries, greater attention in the designing of the monetary and exchange rate policies (Fornaro, 2015). In this research, we investigated the price dependence of a sample of the Sub-Saharan African (SSA) countries in regard to the Euro, considering their exchange rate policy.

According to Toulaboe and Terry (2013) the interest of the countries on the exchange rate regimes lies in its importance for the economic performance, with an emphasis on inflation, the Consumer Price Index (CPI), and its impacts on the growth of activities and other macroeconomic variables. The aforementioned authors highlighted that many industrialized countries adopted the Inflation Targeting Regime (IT), as a tool to ensure price stability, opting for flexible exchange rate regime to increase their policies freedom degrees. However, for some small developing countries, that had a recent history of colonization and closer trade partnerships, the exchange rate regime to control the CPI is more delicate.

The literature, as Friedman (1953), Quirk (1994), Obstfeld and Rogoff (1995), Husain, Mody and Rogoff (2005) and Toulaboe and Terry (2013), pointed out the importance to measure the determinants and effects of the adoption of a policy with a fixed exchange rate regime. Amongst the benefits of this policy, the greater discipline and transparency of the policy makers, the reduction of the costs of transactions and of the inflation expectations, as well, as the consequent macroeconomic stability, can be emphasized. Still, some small open economies with a relative degree of openness, when adopting the fixed exchange rate regime, tend to import the inflation of its main trade partners (Jalles, 2010).

In the countries of the Latin America (LA), consonant to Rodriguez (2016), the action and reputation of the public institutions are determinant aspects on the choice of the exchange rate regime. Among such countries, those with 
democratic institutions and stable political contexts are associated to flexible exchange rate regimes, while the others tend to adopt fixed regimes. Chiu and Willett (2009) argue that regardless of the regime, if the political institutions are weak, the probabilities of occurring an exchange rate crisis increase, and that the adoption of a fixed regime without more solid institutions, may be another source of instabilities. In the same direction, Carmignani, Colombo and Trivelli (2008) expose that the choice of the exchange rate regime is sensitive to the political instabilities.

Based in this context, we estimated the relations of dependence of the CPI of selected SSA countries in relation to the CPI observed in the countries of the European Monetary Zone (EMZ). Thus, using the pairs of stochastic processes, we controlled the results by their exchange rate regimes. Precisely, countries of the Central African Economic and Monetary Community (CEMAC), the West African Economic and Monetary Union (WAEMU), Cape Verde and Sao Tome and Principe were sampled. They were selected because such countries from the CEMAC and the WAEMU benefit from an Exchange Rate Cooperation Agreement with France, while Cape Verde benefits from an agreement with Portugal, since 1998.

With the establishment of the EMZ, since January 1st 1999, the Euro starts to be rated in the currency of each participating country, at a fixed exchange rate, allowing the access of these countries to all of the Euro space. We also report that in Sao Tome and Principe, the Exchange Rate Cooperation Agreement came into effect in January 1 st 2010. Therefore, based on the process of dependence of the CPI resulted by the estimated Copulas, it will be possible for these countries, possibly to review their exchange rate policies, as well as their agreements.

We used a model to study the relations between the CPI dynamics of the sampled countries that capture the changes in the joint distribution function of the pairs of inflation processes. This way, we waived the use of the models with estimators conditioned to the average, correlation measures, common trends and cointegration, or the analysis of the Impulse Response Functions (IRFs). Instead, we adopt the Copula model, proposed by Sklar (1959), which has been widely used in the analysis of the CPI dynamics, as described in Zhang and Jiao (2012), Moreira, Chaiboonsri and Chaitip (2013), Silva (2014) and Antunes (2015).

The use of the linear correlation to verify how much the CPI of the studied countries are dependent on the imported inflation of the countries of the EMZ, would possibly ( $i$ ) ignore the presence of a nonlinear dependence (ii) estimate it conditioned to the average, i.e., a localization measure could not reveal information about the tails' behavior of the CPI distributions. Furthermore, to use such approaches, we need to check the probabilities density functions of the variables, if they are homoscedastic, if they are correct specified in the model, as well, as if there is normality of the residues.

In this perspective, the use of the methodology of Copulas lead to some advances, if we compare to the other methods, previously mentioned. For instance, there is no need of any hypothesis about the distribution of the variables, additionally, it could capture the presence of nonlinear associations, without any prior information about these relations. With this effort, our main contribution is providing empirical evidence of inflation dependence for the selected SSA countries, in order to evaluate the exchange rate policy for each of them.

For the reduced dependencies between the CPI observed among selected SSA countries and the registered in the EMZ, it is possible that a change from the fixed regime linked to the Euro to a flexible regime, could improve the efficiency of the economic policies. Alternatively, for more elastic dependencies observed for those countries in which the regime is flexible, perhaps a change to a fixed regime can be more appropriate, in terms of the inflation control. This strategy will allow consider the countries, assuming as a control variable the type of exchange practicedin each case, seeking to better refinements of the findings of the study.

This paper is divided in five sections, besides this brief introduction. In the second section, the theoretical relations regarding the determinants of the CPI with emphasis on the imported inflation, will be presented. In the third section, the empirical methodology of Copulas is detailed. The fourth section will point out the sample planning and processing. In the fifth section, the obtained results will be displayed. At last, in the sixth section, the key findings are discussed, and in the seventh, conclusions are adressed.

\section{Sub-Saharan African Countries, Trade and Imported Infl ation}

The determinants of the CPI of goods and imported products by the African countries have been widely studied. Blavy (2004), Moriyama (2008), Olubusoye and Oyaromade (2008), Klein and Kyei (2009), Ndanshau (2010), Carvalho, Massala and Santos (2012), and Durevall and Sj (2012) analyzed the cases of Angola, Ethiopia, Nigeria, Kenya, Sudan and Tanzania. Regarding Cape Verde, there are Delgado and Santos (2006), Jalles (2010) and Oliveira, Silva and Lima (2014), whose analyzed the determinants of inflation with attention to the imported causes. They assume Portugal's CPI as a proxy, because since Cape Verdes independence, Portugal is its main economic partner. The results found in the researches aforementioned denote that the CPI of Portugal can explain the CPI of Cape Verde. 
For the countries of the WAEMU, Toe and Lien (2007) and Toe (2011) used the CPI observed in France and other countries from the Eurozone, as a proxy to the external inflation, to explain domestic prices dynamics. They found that such variables contribute to explain the CPI of the countries members of this region. Kinda (2011) sought to verify the sources of inflation in Chad and found that increases in the external prices would lead to the acceleration in the domestic prices. In the case of Sao tome and Principe, no studies were found regarding the external inflation as the source of the domestic prices variation.

According to Saleem et al. (2014) the intensification of the financial and trade relations among small economies and the rest of the world, lead the internal prices to respond more intensely to the variation of the external prices. In this sense, Dornbusch (2001) and Husain et al. (2005) emphasized that in the case of small developing countries, lower CPI can be associated to fixed exchange rate regimes. Moreover, Fischer (1981), Smal (1998), Guerron-Quintana (2011) and Araújo (2015) point that high CPI lead to the malfunctioning of several markets, reducing the level of social welfare in the form of income concentration, making the formation of expectations difficult, decreasing the level of investments, causing disturbances in the Balance of Payments, among other problems.

Sissoko and Dibooglu (2006) argue that regimes with a less flexible exchange rate would be more vulnerable to external crises, given a less elastic reaction of the policy maker, in order to reduce the effects of external shocks, allowing the exchange rate to depreciate. Thus, the costs would be greater for countries more integrated, such as the case of economic blocs of the EMZ and the WAEMU, for example. Further, countries engaged in trade expansion objectives with their partners, without totally losing their fiscal and monetary policy activism, may consider the fixed exchange regime as an alternative to full monetary integration. In terms of the SSA countries, there are important characteristics considered in this research, exposed by periods in Table 1:

Table 1. Characteristics of the SSAcountries

\begin{tabular}{|c|c|c|c|c|c|}
\hline Country & $1991-1995$ & $2001-2005$ & $2006-2010$ & $2011-2014$ & \\
\hline \multicolumn{6}{|c|}{ GDP per capita (US dollars) } \\
\hline Benin & 369.39 & 376.74 & 491.45 & 719.77 & 849.15 \\
\hline B. Faso & 294.79 & 245.21 & 322.54 & 523.12 & 696.62 \\
\hline C. Verde & 1115.04 & 1365.5( & 1838.26 & 3265.17 & 3615.88 \\
\hline I. Coast & 804.53 & 781.50 & 829.32 & 1124.65 & 1315.45 \\
\hline Mali & 385.85 & 343.77 & 420.40 & 692.95 & 880.00 \\
\hline Niger & 247.48 & 186.78 & 213.93 & 343.42 & 446.66 \\
\hline Senegal & 636.19 & 525.34 & 629.71 & 974.62 & 1056.29 \\
\hline Togo & 389.60 & 336.77 & 329.35 & 472.46 & 607.28 \\
\hline \multicolumn{6}{|c|}{ CPI (\%) } \\
\hline Benin & 12.29 & 3.81 & 2.83 & 3.11 & 2.34 \\
\hline B. Faso & 6.72 & 2.54 & 3.02 & 2.61 & 1.71 \\
\hline C. Verde & 7.72 & 4.18 & 1.06 & 3.82 & 2.07 \\
\hline I. Coast & 9.60 & 3.36 & 3.22 & 2.61 & 2.31 \\
\hline Mali & 6.19 & 1.58 & 2.44 & 3.12 & 2.16 \\
\hline Niger & 8.33 & 2.69 & 2.61 & 2.58 & 1.19 \\
\hline Senegal & 7.54 & 1.44 & 1.53 & 2.66 & 1.11 \\
\hline Togo & 10.57 & 2.76 & 2.65 & 3.40 & 2.04 \\
\hline \multicolumn{6}{|c|}{ Public Debt (\% GDP) } \\
\hline Benin & - & - & 38.44 & 22.06 & 28.25 \\
\hline B. Faso & - & - & 45.80 & 26.18 & 28.85 \\
\hline C. Verde & - & 81.09 & 82.58 & 67.55 & 95.43 \\
\hline I. Coast & - & 107.59 & 84.43 & 70.31 & 53.65 \\
\hline Mali & - & - & 49.28 & 20.59 & 26.62 \\
\hline Niger & - & 85.25 & 89.77 & 25.08 & 28.68 \\
\hline Senegal & - & - & 57.37 & 27.79 & 46.17 \\
\hline Togo & - & - & 110.52 & 83.27 & 51.78 \\
\hline \multicolumn{6}{|c|}{ Degree of Economic Opening (DEO) } \\
\hline Benin & 58.33 & 59.10 & 49.93 & 54.97 & 65.31 \\
\hline B. Faso & 34.35 & 36.95 & 33.33 & 39.63 & 63.56 \\
\hline C. Verde & 74.86 & 82.37 & 99.59 & 100.00 & 98.49 \\
\hline I. Coast & 63.68 & 75.85 & 81.44 & 91.30 & 85.43 \\
\hline Mali & 51.18 & 53.03 & 57.22 & 57.99 & 57.02 \\
\hline Niger & 37.40 & 42.52 & 43.32 & 57.03 & 62.95 \\
\hline Senegal & 59.15 & 62.17 & 67.14 & 70.31 & 75.29 \\
\hline Togo & 65.84 & 74.81 & 93.10 & 92.14 & 100.00 \\
\hline
\end{tabular}


Source: Authors' elaboration.

The Table 1 report that Cape Verde is the country with higher GDP per capita of US $\$ 3,615.88$ per year, almost three times of the observed in Ivory Coast, the second place in order of magnitude. Cape Verde is also the country with higher degree of economic opening, just near $100 \%$, which considering the average for the countries of the WAEMU, is around 75\% for the period of 2011 to 2014. Otherwise, is also possible to observe that Cape Verde figure with the higher public debt as a ratio of the GDP $(95.43 \%)$. Not by coincidence, Cape Verde also holds higher standards of inflation. As general, the path higher public debts are accompanied by high CPI.

On the other hand, as described by Fischer (1981), the costs of inflation control depend on its sources, either of the institutional structure, how expectations are formed, if inertial behavior is observed, for example, or arise on the supply side of the economy, due to seasonalities patterns of some goods and services. Additionally, the anti-inflationary benefit depends on the stability, credibility and reputation of the monetary authority. Toulaboe and Terry (2013) point that these conditions are less costly in economies with solid institutions. In this direction, studies about the determinants of the CPI and its control have been evolving to add to the internal factors, the external ones, which started to be incorporated in the analysis of the inflationary dynamics.

Based on the model of Harberger (1963), which considers the monetary base and the output as determinants factors of inflation, Hanson (1985), incorporated the costs of import inflation, in order to verify how the price variations of the imported goods affect the CPI, process that is called imported inflation. In the same way, Kim (2008) developed a model for an open economy, in which the CPI can derive from three main sources: the monetary, the wages and the imported inflation. The imported inflation, our main research subject, resulting from changes in the exchange rate and from external prices. In other words, the CPI resulted of the transmission of import prices in foreign currency. Kim (2008) developed a model by considering that the general price level $\left(p_{t}\right)$ is given by a weighted average of the tradable goods $\left(p_{t}^{t}\right)$ and of the non-tradable goods $\left(p_{t}^{n}\right)$. For better comprehension of the model:

$$
p_{t}=\theta p_{t}^{t}+(1-\theta) p_{t}^{n}
$$

with $0<\theta<1$. The price of the tradable goods is determined by the global market, and can be represented by:

$$
p_{t}^{t}=\varphi e_{t}+k p_{t}^{f}
$$

in which $e_{t}$ and $p_{t}^{f}$ are, respectively, the exchange rate and the external prices, which are the determinant factors of the imported inflation. By the equation (2) the prices of the tradable goods increase because of the depreciation of the exchange rate, or when the prices of the imported goods increase. Regarding the prices of non-tradable goods, the model assumes that they are determined in the domestic monetary market, shifting the demand function of the economy. The equation (3) illustrates this relation:

$$
p_{t}^{t}=\eta\left[m_{t}^{d}-\left(m_{t}^{s}-p_{t}\right)\right]
$$

where $\eta$ is a factor that shows the relation between the global demand of economy and the demand for non-tradable goods. According to the previous equation, the prices are defined by money market equilibrium condition, in which the real supply and demand for money $\left(m_{t}^{s}-p_{t}\right)$ and $\left(m_{t}^{d}-p_{t}^{n}\right)$ respectively, must be equal. In this model the demand for non-tradable goods are a function of wages, goods and the interest rates. Consequently, this model $(i)$ incorporates the monetary inflation that occur when the supply of money is higher than the real output, as well, as (ii) the wage inflation that derives from the increases of wages, what implies in raising the demand for goods and on the unitary costs of production, which, ceteris paribus, translates into a rise the CPI.

However, here we considering that in the WAEMU the variables money supply, interest rates and by consequence, the wages, are stable. This means that the CPI is given mainly by the imported goods. In this sense, the parameter $\eta$ is one of the channels of the studied economies to external shocks. We can identify two distinct models of literature that study the impact of the imported goods on the CPI. There are models such as Gali and Monacelli (2005), that consider the imported goods as consumer goods, and there are the models developed by McCallum and Nelson (2000), that consider the importation as production inputs, with the imported goods having an indirect effect on the CPI.

We highlight that the relation between domestic and external inflation originate from trade flows and factors between borders, which motivates different models concerning the CPI and the exchange rate regime relations. They distinguish giving to some indicators, in terms of its participations on the global trade and its degrees of development. As stated to Poirson (2001), when there is a dominant trade partner, a fixed exchange rate regime is adopted. In opposite, when the economy aims to diversify the production and exportation, it must adopt a flexible regime. 
Facing the presented facts, this research aims to estimate the dependencies between $p_{t}^{t}$ and $p_{t}^{f}$ in the equation (2), however more than estimate the elasticities, we proposed to control the sample for the type of exchange rate policy $e t$ adopted in each country. As a result, was possible to identify which exchange rate policy is the most appropriate for each country, in agreement to the CPI. This empirical evidence consists of a robust measure function, which, as mentioned, considers information on the entire joint distribution of the studied CPI. Otherwise, for the cases of lower dependencies between these prices, the exchange policy could be revised to a flexible regime. Our contribution seems to be interesting, even than comparing with the approach of the CPI as a stable parameter $(\eta)$ (Kim, 2008), by using structural modeling of linear relationships, which parameters are conditioned to average of the CPI observed.

\section{Methodology}

In order to verify the dependence between the CPI of the selected countries, in relation to the observed in the Eurozone, we used the Copula model. It allows to estimate the joint distribution between two or more random variables, as a function of its marginals. According to Nelsen (2006), the Copulas are functions used to describe dependence of multivariate joint distribution, which can be written in terms of its own uni variate marginal distribution functions. The application of Copulas is based on the Sklar (1959) theorem. Formally, it exposed that if $H$ is a joint distribution function with marginals $F$ and $G$, there is a Copula $C$, given that $x$ and $y$ belong to $R$. Thus, we can write:

$$
H(x, y)=C(F(x), G(y))
$$

Therefore, the estimation of Copulas, in substitution of estimate $\eta$ by using linear models, consists in finding a parametric Copula that better represents the bivariate probability distribution function $H$. Given that the functional form of $F(x)$ and $G(x)$ are unknown, the procedure of pseudo-observations is to estimate a diversity of parametric bivariate Copulas, in order to define which of them better characterize the relation of the CPI dependence of the selected SSA countries', with the observed in the countries of the Eurozone.

More than create independent multivariate probability distribution functions of the format of the marginal distributions, through the theory of Copulas, it is possible to estimate the dependence of the variables. Commonly, the linear correlation is also used for such purpose. Although, this method is not indicated when there is no normality of the distribution of the observations, or when asymmetry or distributions with heavy tails are detected, as well, as when the dependence follows a nonlinear dynamic.

Embrechts, McNeil and Straumann (2002) emphasize that a correlation of two variables equal to zero do not mean independence, in case both of them are not normally distributed. Hence, given the diverse statistical characteristics from the used data, we estimate different Copulas, seeking for better fit of the different functional forms. There is a considerable diversity of Copulas that present specific dependence structure, among which we can highlight the Archimedean, the elliptical and the extreme-value. Amid the characteristics of an Archimedean Copula, there is the possibility of assuming the asymmetric tail dependence, which makes it widely attractive to applications in the estimation of losses in the financial markets, as investigated in Zhang and Jiao (2012). With similar purpose, we also have the Copulas of Frank, Clayton, Gumbel, Ali-Mikhail-Haq (AMH) and Joe.

The elliptical Copula have many properties as the multivariate Gaussian distribution, that fits the full modeling multivariate extremes and other forms of non-normal dependencies. We can also report the Gaussian and the $t$-student's Copula. Finally, extreme-value Copula have as a main attribute the possibility of modeling the extreme-value dependence, i.e., the cases of concentration of the observations in the distributions' tails. This way, they are useful to modeling the financial markets events. In this category there are Galambos, Husler-Reiss, Tawn and $t$-Extreme Value (T-EV) Copulas. The Table 2 denote the differences of the Copulas used. 
Table 2. Parametric Copulas

\begin{tabular}{cc}
\hline Clayton & $C\left(u_{1}, u_{2} ; \theta\right)=\left(u_{1}^{-\theta}+u_{2}{ }^{-\theta}-1\right)^{-1 / \theta}$ \\
\hline Frank & $C\left(u_{1}, u_{2} ; \theta\right)=-\theta^{-1} \log \left\{1+\frac{\left(e^{-\theta u_{1}}-1\right)\left(e^{-\theta u_{2}}-1\right)}{e^{-\theta}-1}\right\}$ \\
\hline Gumbel & $C\left(u_{1}, u_{2} ; \theta\right)=\exp \left(-\left(\left(-\log u_{1}\right)^{\theta}+\left(-\log u_{2}\right)^{\theta}\right)^{1 / \theta}\right)$ \\
\hline AMH & $C\left(u_{1}, u_{2} ; \theta\right)=\frac{u_{1} u_{2}}{1-\theta\left(1-u_{1}\right)\left(1-u_{2}\right)}$ \\
\hline Joe & $C\left(u_{1}, u_{2} ; \theta\right)=1-\left[\left(1-u_{1}\right)^{\theta}+\left(1-u_{2}\right)^{\theta}-\left(1-u_{1}\right)^{\theta}\left(1-u_{2}\right)^{\theta}\right]^{1 / \theta}$ \\
\hline Gaussian & $C\left(u_{1}, u_{2} ; \theta\right)=\int_{-\infty}^{\Phi^{-1}\left(u_{1}\right)} \int_{-\infty}^{\Phi^{-1}\left(u_{2}\right)} \frac{1}{2 \pi\left(1-\theta^{2}\right)^{1 / 2}} \times\left\{\frac{-\left(s^{2}-2 \theta s t+t^{2}\right)}{2\left(1-\theta^{2}\right)}\right\} d s d t$ \\
\hline & $C\left(u_{1}, u_{2} ; \theta, v\right)=\int_{-\infty}^{t_{v}^{-1}\left(u_{1}\right)} \int_{-\infty}^{t_{v}^{-1}\left(u_{2}\right)} \frac{1}{2 \pi\left(1-\theta^{2}\right)^{1 / 2}}\left\{1+\frac{\left(s^{2}-2 \theta s t+t^{2}\right)}{v\left(1-\theta^{2}\right)}\right\}$
\end{tabular}

\begin{tabular}{cc} 
T-student & $C\left(u_{1}, u_{2} ; \theta\right)=u_{1} u_{2} \exp \left(\left(\left(-\log u_{1}\right)^{-\theta}+\left(-\log u_{2}\right)^{-\theta}\right)^{-1 / \theta}\right)$ \\
\hline Galambos & $C\left(u_{1}, u_{2} ; \theta\right)=\exp \left\{-\tilde{u}_{1} \Phi\left(\theta^{-1}+\frac{1}{2} \theta \ln \left(\frac{\tilde{u}_{2}}{\tilde{u}_{1}}\right)\right)--\tilde{u}_{2} \Phi\left(\theta^{-1}+\frac{1}{2} \theta \ln \left(\frac{\tilde{u}_{1}}{\tilde{u}_{2}}\right)\right)\right\}$ \\
\hline
\end{tabular}

Tawn

$$
\begin{gathered}
C\left(u_{1}, u_{2} ; \theta\right)=u_{1} u_{2} \exp \left\{-\theta \frac{\log u_{1} \log u_{2}}{\log \left(u_{1} u_{2}\right)}\right\} \\
C\left(u_{1}, u_{2} ; \theta, v\right)=\exp \left(\log \left(u_{1} u_{2}\right) \boldsymbol{A}_{\theta, v}\left(\frac{\log \left(u_{1}\right)}{\log \left(u_{1} u_{2}\right)}\right)\right),
\end{gathered}
$$

where:

T-EV

$$
\begin{aligned}
& \boldsymbol{A}_{\theta, v}(w)=w t_{v+1}\left(\frac{\left(\frac{w}{1-w}\right)^{1 / v}-\theta}{\sqrt{1-\theta^{2}}} \sqrt{v+1}\right)+(1-w) t_{v+1}\left(\frac{\left(\frac{1-w}{w}\right)^{1 / v}-\theta}{\sqrt{1-\theta^{2}}} \sqrt{v+1}\right) \\
& C\left(u_{1}, u_{2} ; \theta\right)=\frac{\left[1+(\theta-1)\left(u_{1}+u_{2}\right)\right]-\sqrt{\left[1+(\theta-1)\left(u_{1}+u_{2}\right)\right]-4 u_{1} u_{2} \theta(\theta-1)}}{2(\theta-1)}
\end{aligned}
$$

Source: Authors'elaboration.

The models of Copulas given by the Spearman's Rho and Kendall's Tau are the most popular. As stated by Nelsen (2006), both are measures based on the positions or rankings of the variables and not on its effective values. This

\begin{tabular}{|c|c|c|c|}
\hline Spearman's Rho & Kendall's Tau & Tail Index Inferior & Tail Index Superior \\
\hline$\rho_{X, Y}=12 \iint_{I^{2}} C(u, v) d u d v-3$ & $\tau_{X, Y}=4 \iint_{I^{2}} C(u, v) d C(u, v)-1$ & $\lambda_{L}=\lim _{v \rightarrow 0^{+}} \frac{C(v, v)}{v}$ & $\lambda_{U}=\lim _{v \rightarrow 1^{-}} \frac{S(v, v)}{1-v}$ \\
\hline
\end{tabular}
way, with the objective of modeling the dependence of the inferior and superior tails of the respective distribution function of the variables, we estimated the Tail Index. The functional forms can be seen in the Table 3:

Table 3. Dependence Measures

Source: Authors' elaboration from Nelsen(2006).

The Spearman's Rho and the Kendall's Tau are nonparametric measures of dependence that consider the degree of general association between the variables, which vary between [-1, 1], while the Tail Index consider the concentration of dependence in the inferior and superior tails, which vary between [0, 1]. Howe ver, before the application of these tests, we must estimate the test of independence of Genest and Remillard (2004). It assumes as the null hypothesis that the variables present independence between themselves. Formally, the statistic of the test is given by:

$$
T_{A, n}^{S}=\frac{1}{n} \sum_{i=1}^{n-p+1} \sum_{k=1}^{n-p+1} \prod_{j \in A}\left\{\frac{2 n+1}{6 n}+\frac{R_{i+j-1}\left(R_{i+j-1}-1\right)}{2 n(n+1)}+\frac{R_{k+j-1}\left(R_{k+j-1}-1\right)}{2 n(n+1)}-\frac{\max \left(R_{i+j-1}, R_{k+j-1}\right)}{n+1}\right\}
$$


It is common after the Copula estimation to verify its fit, in order to avoid wrong considerations about the relations of dependence. Genest, Remillard and Beaudoin (2009) developed an adjustment test named as Goodness-of-fit, which consists in comparing the parametric Copulas with the empirical ones, under the null hypothesis that the chosen one is appropriate to model the relation of dependence. The Goodness-of-fit test is based on the following empirical process:

$$
\mathbb{C}_{n}(u)=\sqrt{N\left(C_{n}-C_{\theta n}(u)\right)} \quad u \in[0,1]^{d}
$$

where $C_{\theta n}$ represents the parametric Copula and $C_{n}$ the empirical one, defined by:

$$
C_{n}(u)=\frac{1}{n} \sum_{i=1}^{n} 1\left(U_{i 1} \leq u_{1}, \ldots, U_{i d} \leq u_{d}\right)
$$

The statistic of the Goodness-of-fit test is given by:

\section{Sample Design and Data Processing}

$$
S_{n}=\int_{[0,1]} \mathbb{C}_{n}(u)^{2} d C_{n}(u)
$$

For this study, we selected the CPI observed in the countries of the Eurozone and the SSA countries, which adopted fixed exchange rate regimes with the Euro, as well as some countries that have flexible exchange rate regimes. They were selected and organized as illustrated in the Table 4 . For all of the sampled countries, the data is regarding the

\begin{tabular}{|c|c|c|c|}
\hline Country & Source & Starting periods & Fixed Regime \\
\hline C. Verde & Bank of Cape Verde & Jan/98 & Yes \\
\hline S. T. Principe & Banco de Sao Tome and Principe & Jan/09 & Yes \\
\hline Benin & Banque Centrale des Etats de l'Afrique de l'Ouest & $\mathrm{Jan} / 98$ & Yes \\
\hline B. Faso & Banque Centrale des Etats de l'Afrique de l'Ouest & $\mathrm{Jan} / 98$ & Yes \\
\hline I. Coast & Banque Centrale des Etats de l'Afrique de l'Ouest & Jan/98 & Yes \\
\hline G. Bissau & Banque Centrale des Etats de l'Afrique de l'Ouest & $\mathrm{Jul} / 02$ & Yes \\
\hline Mali & Banque Centrale des Etats de l'Afrique de l'Ouest & Jan/98 & Yes \\
\hline Niger & Banque Centrale des Etats de l'Afrique de l'Ouest & Jan/98 & Yes \\
\hline Senegal & Banque Centrale des Etats de l'Afrique de l'Ouest & Jan/98 & Yes \\
\hline Togo & Banque Centrale des Etats de l'Afrique de l'Ouest & Jan/98 & Yes \\
\hline \multirow[t]{2}{*}{ Chad } & Institut National de la Statistique, des & fev/07 & Yes \\
\hline & Etudes Economiques et Demographiques & & \\
\hline Rwanda & National Institute of Statistics of Rwanda & Jan/98 & No \\
\hline Ghana & Ghana Statistical Service & $\mathrm{Jan} / 98$ & No \\
\hline Mauritius & Statistics Mauritius & Jan/98 & No \\
\hline Malawi & Reserve Bank of Malawi & $\mathrm{Jan} / 01$ & No \\
\hline South Africa & South African Reserve Bank & $\mathrm{Jan} / 02$ & No \\
\hline Nigeria & Central Bank of Nigeria & $\operatorname{mar} / 02$ & No \\
\hline Seychelles & National Bureau of Statistics & $\mathrm{Jan} / 07$ & No \\
\hline EMZ & European Central Bank & Jan/92 & - \\
\hline
\end{tabular}
period until December 2015.

Table 4. Countries characteristics and data sources

Source: Authors' elaboration.

As mentioned, in the search for more robust estimations of parametric Copulas we controlled the results for the exchange rate regimes (fixed and flexible) and for the rule periods of international agreements in the selected SSA countries. Therefore, the time series used were also organized in three different subsamples, considering the (a) monthly frequency, (b) quarterly frequency and (c) annualized frequency. All of them include the period after January 1999, which mark the dates in which the countries adopted its exchange rate regimes. In this sense, it is possible that are differences in the time series data used in the estimations of the models (a) to (c), regard to the number of observations. We also report in the Table 5 that in unitary root tests (Augmented Dickey-Fuller (ADF), Phillips-Perron (PP), Kwiatko wski, Phillips, Schmidt and Shin (KPSS)), the stationarity was not rejected in most part of the CPI series, considering the confidence level of 5\%, i.e., they are $\mathrm{I}(0)$. 
Table 5. Estimated unitary root tests for the CPI for the countries

\begin{tabular}{|c|c|c|c|c|c|c|c|c|c|c|c|c|}
\hline \multicolumn{13}{|c|}{ Fixed Regimes } \\
\hline & EMZ & Benin & B. Faso & $\begin{array}{c}\text { C. } \\
\text { Verde }\end{array}$ & Chad & $\begin{array}{c}\text { G. } \\
\text { Bissau }\end{array}$ & $\begin{array}{c}\text { I. } \\
\text { Coast }\end{array}$ & Mali & Niger & STP & Senegal & Togo \\
\hline \multicolumn{13}{|c|}{ (a) Monthly Sample } \\
\hline $\mathrm{ADF}$ & $-4.73^{*}$ & $-6.61 *$ & $-7.34 *$ & $-6.16^{*}$ & $-5.77 *$ & $-7.03^{*}$ & $-8.26^{*}$ & $-8.82^{*}$ & $-7.41 *$ & $-4.36 * *$ & $-7.35^{*}$ & $-6.09 *$ \\
\hline PP & $\begin{array}{c}-148.28 \\
*\end{array}$ & $\begin{array}{c}-189.20 \\
*\end{array}$ & $\begin{array}{c}-199.68 \\
*\end{array}$ & $\begin{array}{c}-178.52 \\
*\end{array}$ & $\begin{array}{c}-84.73 \\
*\end{array}$ & $-140.09 *$ & $\begin{array}{c}-157.97 \\
*\end{array}$ & $\begin{array}{c}-134.63 \\
*\end{array}$ & $\begin{array}{c}-138.65 \\
*\end{array}$ & $-55.71 *$ & $\begin{array}{c}-134.70 \\
*\end{array}$ & $\begin{array}{c}-153.93 \\
*\end{array}$ \\
\hline $\begin{array}{c}\text { KPS } \\
\text { S }\end{array}$ & $0.26^{*}$ & $0.06^{*}$ & $0.05 *$ & $0.15^{*}$ & $0.10^{*}$ & $0.14 *$ & $0.08 *$ & $0.03 *$ & $0.03 *$ & 1.63 & $0.04 *$ & $0.04 *$ \\
\hline \multicolumn{13}{|c|}{ (b) Quarterly Sample } \\
\hline $\mathrm{ADF}$ & $\begin{array}{c}-3.27 * * \\
*\end{array}$ & $-4.30 *$ & $-4.63 *$ & $-3.63^{* *}$ & -1.62 & -2.95 & $-4.70^{*}$ & -3.49 & $-3.87 * *$ & $-6.72 *$ & -3.47 & $-4.15^{*}$ \\
\hline $\mathrm{PP}$ & $\begin{array}{c}-103.76 \\
*\end{array}$ & $-66.48^{*}$ & $-52.42^{*}$ & $-45.23^{*}$ & $\begin{array}{c}-55.09 \\
*\end{array}$ & $-33.05^{*}$ & $-60.11 *$ & $-53.41 *$ & $-45.55^{*}$ & 0.69 & $-43.15^{*}$ & $-43.67^{*}$ \\
\hline $\begin{array}{c}\text { KPS } \\
\text { S }\end{array}$ & 0.45 & $0.11 *$ & $0.05 *$ & $0.14 *$ & $0.43^{* *}$ & $0.11 *$ & $0.12 *$ & $0.05^{*}$ & $0.03^{*}$ & $-28.05 *$ & $0.04 *$ & $0.06^{*}$ \\
\hline \multicolumn{13}{|c|}{ (c) Annualized Sample } \\
\hline $\mathrm{ADF}$ & $\begin{array}{c}-3.32 * * \\
*\end{array}$ & $-3.67 * *$ & $-4.44^{*}$ & $-4.003^{*}$ & -2.13 & -2.83 & $-4.37 *$ & $-3.70 * *$ & $-4.47^{*}$ & $\begin{array}{c}-3.32 * * \\
*\end{array}$ & $\begin{array}{c}-3.34 * * \\
*\end{array}$ & $-4.99 *$ \\
\hline PP & $\begin{array}{c}-18.08^{*} \\
* *\end{array}$ & $-31.87 *$ & $\begin{array}{c}-21.25 * \\
*\end{array}$ & -17.25 & -13.53 & $\begin{array}{c}-19.39 * * \\
*\end{array}$ & $-35.09 *$ & -17 & $\begin{array}{c}-19.2 * * \\
*\end{array}$ & -1574 & $\begin{array}{c}-17.96^{*} \\
* *\end{array}$ & $\begin{array}{c}-24.86^{*} \\
*\end{array}$ \\
\hline $\begin{array}{c}\text { KPS } \\
\text { S }\end{array}$ & 0.906 & $0.27 *$ & $0.20 *$ & $0.27 *$ & 0.56 & $0.35^{*}$ & $0.30 *$ & $0.23^{*}$ & $0.17 *$ & 3.18 & $0.33^{*}$ & $0.20 *$ \\
\hline \multicolumn{13}{|c|}{ Flexible Regimes } \\
\hline & Ghana & Malawi & $\begin{array}{c}\text { Mauriti } \\
\text { us }\end{array}$ & Nigeria & $\begin{array}{c}\text { Rwand } \\
\text { a }\end{array}$ & $\begin{array}{l}\text { Seychell } \\
\text { es }\end{array}$ & $\begin{array}{c}\text { S.Afric } \\
\text { a }\end{array}$ & & & & & \\
\hline \multicolumn{13}{|c|}{ (a) Monthly Sample } \\
\hline $\mathrm{ADF}$ & $-5.95^{*}$ & $-5-59 *$ & $-4.86^{*}$ & $\begin{array}{c}-137.62 \\
*\end{array}$ & $-4.40 *$ & $-3.77 * *$ & $-4.11 *$ & & & & & \\
\hline PP & $\begin{array}{c}-220.34 \\
*\end{array}$ & $\begin{array}{c}-203.74 \\
*\end{array}$ & $\begin{array}{c}-146.91 \\
*\end{array}$ & $-6.40 *$ & $\begin{array}{c}-118.35 \\
*\end{array}$ & $-93.12^{*}$ & $-96.11 *$ & & & & & \\
\hline $\begin{array}{c}\text { KPS } \\
\text { S }\end{array}$ & $0.05^{*}$ & $0.03^{*}$ & $0.44 * *$ & $0.13^{*}$ & $0.22 *$ & $0.61 * *$ & $0.19 *$ & & & & & \\
\hline \multicolumn{13}{|c|}{ (b) Quarterly Sample } \\
\hline $\mathrm{ADF}$ & $-4.57 *$ & $4.35^{*}$ & -2.40 & $-3.88 * *$ & $-4.15^{*}$ & -2.3 & $-3.17 *$ & & & & & \\
\hline PP & $-41.82^{*}$ & $-52.38 *$ & $-50.61 *$ & $-41.64^{*}$ & $\begin{array}{c}-37.72 \\
*\end{array}$ & $-18.91 * *$ & $\begin{array}{c}-20.26^{*} \\
*\end{array}$ & & & & & \\
\hline $\begin{array}{c}\text { KPS } \\
\text { S }\end{array}$ & $0.55^{*}$ & $0.05^{*}$ & $0.56 * *$ & $0.16^{*}$ & $0.22 *$ & $0.52 * *$ & $0.15^{*}$ & & & & & \\
\hline \multicolumn{13}{|c|}{ (c) Annualized Sample } \\
\hline $\mathrm{ADF}$ & $-4.52 *$ & $-3.57 * *$ & -2.54 & $-4.17 * *$ & $\begin{array}{c}-4.18^{*} \\
*\end{array}$ & -2.22 & $-3.89 * *$ & & & & & \\
\hline PP & -13.29 & $\begin{array}{c}-26.11 * \\
*\end{array}$ & -14.04 & $\begin{array}{c}-21.45^{*} \\
*\end{array}$ & -13.40 & -6.37 & -13.02 & & & & & \\
\hline $\begin{array}{c}\text { KPS } \\
\text { S }\end{array}$ & 1.39 & $0.35^{*}$ & 0.94 & 0.80 & 0.72 & 1.45 & 0.84 & & & & & \\
\hline
\end{tabular}

Note: $* 1 \%$ of significance; $* * 5 \%$ of significance; $* * * 10 \%$ of significance.

Source: Authors' elaboration.

Also, the marginal functions of the variables were not filtered or modeled, in order not to change the autocorrelation and volatility structures, behaviors that we want to capture. Hence, the arguments of the bivariate Copulas with residues i.i.d. are less affected by any bias. Our purpose was also to understand the volatility of the dependence relations, since their patterns reveal important information of the supply side and of the demand side of the studied economies.

The descriptive statistics can be found in the Table 12 and Table 13, located in Appendix A. By analyzing such data, we notice that the CPI observed in the countries of the EMZ indicates a lower monthly average, if compared with the observed in the other studied countries, under different conditions. Alternatively, Sao Tome and Principe appears as the country with the greatest inflationary problem in whole period, with the CPI average of $0.72 \%$ per month. The countries of the WAEMU, Benin, Ivory Coast and Togo present the higher average of the CPI. Through the extreme values of the CPI, we observe that the monthly data demonstrate a greater kurtosis 
among countries.

Consequently, the distributions are heavy-tailed, which are e vidence high volatility of the CPI in these countries. We also can verify that the extreme negative values of the monthly inflation of the EMZ countries were more frequent. It was highlighted by the predominant negative asymmetry in the distribution observations. Finally, Jarque-Bera's statistics denote that in the majority of the cases, except for Senegal and Guinea-Bissau, the null hypothesis of normality was rejected, considering the significance level of $1 \%$. This result reinforces the need of use methodologies that are not limited to normal distributions, linear relationships, or estimations conditioned to the average of the CPI observed.

According to the Table 12, we verify that the most significant differences between the subsamples of the quarterly (b) and monthly (a) frequency data were concentrated in their distributions. The quarterly CPI data were less asymmetric than the registered for the monthly subsamples. Through Jarque Bera's test we can see that the normality hypothesis of the distribution was not rejected when adopted the significance level of $5 \%$, except for Ivory Coast. For the annualized CPI data (c), Jarque Bera's test suggested that only for Cape Verde, Ivory Coast, Mali, Senegal and Sao Tome and Principe it was not possible to reject the null hypothesis of normal distribution.

In contrast, the descriptive statistics of the CPI observed in the subsample of the countries with flexible exchange rate regimes are presented in the Table 13. The CPI in these countries were higher than the in the EMZ countries, as well as regarding the subsample of the countries that follow a fixed exchange rate regime. Among them, Ghana and Malawi evidence the highest inflationary average among studied countries. The distribution of the monthly data demonstrates positive asymmetry, which point out that the positive values of the CPI were more often, except for the case of the CPI of the EMZ countries.

The monthly CPI frequency data (a) for all of the studied countries, except for Malawi and South Africa, are heavy-tailed, which reveal the CPI volatility. Jarque Bera's test expose that only for these countries it is not possible to reject the null hypothesis of normality, considering the significance level of $1 \%$. For the quarterly subsample (b), the non-normality of series was verified in the CPI of Rwanda, South Africa, Nigeria and Seychelles. Also, it was not possible to reject the normality hypothesis of the distribution of the annualized CPI data in South Africa's case.

\section{Results}

Before the tests of which Copulas best fits the CPI data, it is necessary to verify the presence of independence among them. This way, the independence test of Genest and Remillard (2004) was estimated, under the null hypothesis that the variables present a relation of independence between themselves. The statistics of this test are displayed in the Table 6.

Table 6. Test of independence

\begin{tabular}{|c|c|c|c|c|}
\hline Country & (a) Monthly & (a(-1)) One lag & (b) Quarterly & (c) Annualized \\
\hline & & Fixed Regime & & \\
\hline C. Verde & 0.039 & $0.078^{* *}$ & 0.038 & $0.334^{*}$ \\
\hline S. T. Principe & 0.021 & 0.028 & $0.106^{*}$ & $0.482 *$ \\
\hline Benin & 0.029 & $0.374 *$ & $0.179 *$ & $0.847^{*}$ \\
\hline B. Faso & 0.019 & $0.155^{*}$ & $0.121 *$ & $0.745^{*}$ \\
\hline I. Coast & 0.044 & $0.153 *$ & $0.075^{* *}$ & $0.793^{*}$ \\
\hline G. Bissau & 0.024 & 0.020 & 0.035 & \\
\hline Mali & 0.031 & 0.032 & 0.039 & $0.628^{*}$ \\
\hline Niger & 0.023 & $0.089 * *$ & $0.058 * * *$ & $0.502^{*}$ \\
\hline Senegal & 0.037 & $0.093 *$ & $0.081 * *$ & $0.711^{*}$ \\
\hline Togo & 0.044 & $0.179 *$ & $0.056^{* * * *}$ & $0.293^{*}$ \\
\hline \multirow[t]{2}{*}{ Chad } & $0.067^{* *}$ & 0.019 & 0.030 & $0.086^{*}$ \\
\hline & & Flexible Regime & & \\
\hline$\overline{\text { Rwanda }}$ & 0.052 & 0.029 & 0.025 & $0.326^{*}$ \\
\hline Ghana & 0.030 & $0.171^{*}$ & $0.06^{* *}$ & $0.136^{*}$ \\
\hline Malawi & $0.056^{* *}$ & $0.144^{*}$ & $0.070^{* *}$ & $0.165^{*}$ \\
\hline South Africa & $0.075^{* *}$ & $0.107^{*}$ & 0.034 & $0.167^{*}$ \\
\hline Nigeria & 0.023 & 0.012 & 0.014 & $0.131^{*}$ \\
\hline Mauritius & $0.067 * *$ & $0.108^{*}$ & 0.038 & $0.520^{*}$ \\
\hline Seychelles & 0.022 & 0.024 & 0.014 & $0.114^{*}$ \\
\hline
\end{tabular}


Note: $* 1 \%$ of significance; $* * 5 \%$ of significance; $* * * 10 \%$ of significance.

Source: Authors' elaboration.

The obtained results considering a significance level of $5 \%$ for the monthly subsamples indicate that the hypothesis of independence cannot be rejected, except for Sao Tome and Principe, for the sample that includes the total period, and Chad, in the period after ACC. Hence, the same test was performed considering the CPI of the EMZ countries with one lag, denoted by $(\mathrm{a}(-1))$. This functional form intended to represent the average time spent in exportation and importation operations in these countries, as reported. In this case, considering the significance level of 5\%, the results point out that the null independence hypothesis was rejected, except for Sao Tome and Principe, Guinea-Bissau, Mali and Chad. For the quarterly data cases (b), only for Cape Verde, Guinea-Bissau, Mali and Chad such hypothesis was not rejected. Lastly, we verified that, when we consider the annualized CPI (c), the null independence hypothesis of the CPI was rejected in all of the cases.

For the countries with flexible exchange regimes, the results of the independence test suggest that for the monthly subsample (a), the independence hypothesis between the series was rejected, except for Malawi, Mauritius and South Africa. Considering the monthly frequency with one lag $(\mathrm{a}(-1))$, we verified that besides these three countries, the CPI in Ghana started to have a possible relation of dependence with the observed in the EMZ countries. For the quarterly frequency (b), we notice that the independence hypothesis was not verified for Malawi and Ghana. Finally, in the light of the test for the annualized subsample (c), the results displayed the rejection of the null independence hypothesis. Since the independence hypothesis prevailed for both types of exchange rate regimes of the countries when the monthly frequency (a) was used, the estimations presented in this research were realized using the monthly frequency with one lag $(a(-1))$, using the quarterly frequency subsample (b), and the annualized subsample (c). We also estimated the parameters of dependence considering the monthly frequency (a), and in both types of exchange rate regimes, the results were statistically insignificant.

Furthermore, the log-likelihood was the criteria to determine which Copula functional form had the best fit for the CPI data. In the Table 7 there is the information regarding the countries which adopted the fixed exchange rate regimes. The estimation results display the predominance of the Frank Copula for the monthly subsample with one lag (a(-1)) (Burkina Faso, Mali and Togo) and the Gaussian (Guinea-Bissau, Niger and Chad), followed by the AMH (Benin and Senegal). For the quarterly frequency subsample (b), the Copulas of Clayton (Sao Tome and Principe, Senegal and Chad), the Hustler-Reiss (Burkina Faso, Mali e Togo), the Gaussian (Cape Verde and Ivory Coast) and the $t$-Student Copula (Guinea-Bissau and Senegal) were that provided the best fits with regard to the CPI of the EMZ countries. For the annualized CPI (c), we report the Copula of Hustler-Reiss (Cape Verde, Burkina Faso and Guinea-Bissau), the Joe (Mali and Niger) and the Gaussian (Benin e Togo) evidenced the best fits among other Copulas. 
Table 7. Log-likelihood of estimated Copulas for the countries with fixed regimes

\begin{tabular}{|c|c|c|c|c|c|c|c|c|c|c|c|c|}
\hline $\begin{array}{l}2 \\
\stackrel{E}{E}\end{array}$ & 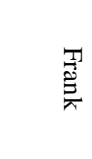 & $\begin{array}{l}\stackrel{2}{\dddot{2}} \\
\stackrel{0}{9}\end{array}$ & 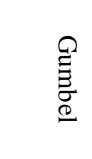 & 坣 & 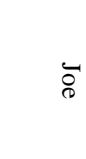 & 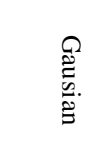 & $\begin{array}{l}\overrightarrow{1} \\
\stackrel{\dot{\Xi}}{\Xi} \\
\stackrel{\Xi}{\Xi} \\
\stackrel{\Xi}{ }\end{array}$ & 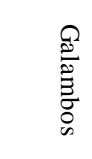 & 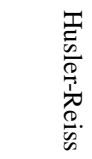 & 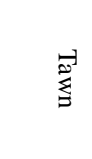 & 柋 & 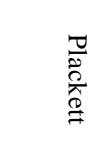 \\
\hline \multicolumn{13}{|c|}{ (a(-1)) One Lag Sample } \\
\hline C. Verde & 2.18 & 1.48 & NA & 1.66 & NA & 0.91 & 1.30 & NA & NA & NA & 0.00 & 2.31 \\
\hline $\begin{array}{l}\text { S. T. } \\
\text { Principe }\end{array}$ & 0.01 & 0.00 & 0.57 & 0.01 & 038 & 0.25 & 023 & 074 & 077 & 029 & 065 & 0.01 \\
\hline Benin & $\begin{array}{l}0.01 \\
17.16\end{array}$ & $\begin{array}{l}0.00 \\
17.97\end{array}$ & 7.81 & 20.23 & $\begin{array}{l}0.38 \\
2.18\end{array}$ & $\begin{array}{l}0.25 \\
15.65\end{array}$ & 15.58 & 8.53 & 8.88 & 5.67 & 7.80 & 16.16 \\
\hline B. Faso & 6.98 & 2.86 & 4.09 & 6.23 & 2.69 & 6.68 & 6.58 & 4.92 & 5.32 & 2.49 & 4.17 & 6.27 \\
\hline I. Coast & 5.81 & 2.30 & 5.67 & 5.32 & 4.86 & 5.94 & 5.87 & 6.14 & 6.32 & 4.54 & 5.74 & 5.27 \\
\hline G. Bissau & 0.72 & 1.36 & 0.36 & 0.77 & 0.06 & 1.37 & 1.30 & 0.89 & 1.03 & NA & 0.53 & 0.72 \\
\hline Mali & 0.74 & 0.09 & 0.20 & 0.73 & 0.08 & 0.63 & 0.59 & 0.43 & 0.50 & 0.04 & 0.26 & 0.70 \\
\hline Niger & 3.80 & 3.81 & 1.48 & 4.02 & 0.31 & 4.65 & 4.56 & 2.31 & 2.61 & 0.37 & 1.67 & 3.45 \\
\hline Senegal & 3.11 & NA & NA & 3.64 & NA & 1.73 & 1.73 & NA & NA & NA & NA & 3.04 \\
\hline Togo & 8.20 & 4.69 & 4.36 & 7.60 & 2.29 & 7.56 & 7.47 & 5.07 & 5.39 & 2.69 & 4.43 & 7.57 \\
\hline Chad & 0.21 & 0.11 & 0.06 & 0.20 & 0.01 & 0.25 & 0.24 & 0.19 & 0.22 & NA & 0.11 & 0.19 \\
\hline \multicolumn{13}{|c|}{ (b) Quarterly Sample } \\
\hline C. Verde & 0.00 & 0.16 & NA & 0.00 & NA & 0.23 & 0.22 & NA & NA & NA & 0.98 & 0.00 \\
\hline $\begin{array}{l}\text { S. T. } \\
\text { Principe }\end{array}$ & 3.05 & 6.36 & 1.74 & 5.59 & 0.38 & 3.34 & 4.00 & 1.69 & 1.67 & 1.67 & 1.71 & 3.38 \\
\hline Benin & 8.71 & 7.93 & 6.79 & 8.14 & 4.59 & 8.41 & 8.39 & 6.65 & 6.53 & 6.54 & 6.70 & 8.18 \\
\hline B. Faso & 5.16 & 2.54 & 5.88 & 3.85 & 5.71 & 5.86 & 5.80 & 6.50 & 6.86 & 4.91 & 5.99 & 4.76 \\
\hline I. Coast & 2.83 & 1.33 & 2.37 & 2.51 & 2.01 & 2.89 & 2.83 & 2.65 & 2.79 & 1.78 & 2.41 & 2.48 \\
\hline G. Bissau & 0.45 & 0.91 & 0.71 & 0.40 & 0.55 & 0.60 & 1.86 & 0.55 & 0.49 & 0.90 & 0.68 & 0.51 \\
\hline Mali & 0.24 & 0.02 & 0.15 & 0.22 & 0.13 & 0.32 & 0.29 & 0.32 & 0.37 & 0.00 & 0.21 & 0.22 \\
\hline Niger & 1.34 & 1.83 & 0.91 & 1.40 & 0.43 & 1.81 & 1.78 & 1.16 & 1.27 & 0.50 & 0.96 & 1.24 \\
\hline Senegal & 1.47 & NA & NA & NA & NA & 0.19 & 3.35 & NA & NA & NA & NA & 1.70 \\
\hline Togo & 1.68 & 0.42 & 1.47 & 1.44 & 1.40 & 1.79 & 1.74 & 1.78 & 1.88 & 0.80 & 1.57 & 1.42 \\
\hline Chad & 0.18 & 0.21 & NA & 0.15 & NA & 0.13 & 0.16 & NA & NA & NA & NA & 0.18 \\
\hline \multicolumn{13}{|c|}{ (c) Annualized Sample } \\
\hline $\begin{array}{l}\text { C. Verde } \\
\text { S. T. }\end{array}$ & 13.25 & 5.75 & 16.08 & 10.30 & 15.50 & 14.67 & 14.59 & 16.92 & 17.26 & 14.12 & 16.23 & 12.45 \\
\hline Principe & 30.31 & 24.99 & 22.02 & NA & 14.43 & 28.28 & 28.22 & 22.14 & 22.12 & NA & 21.78 & 27.54 \\
\hline Benin & 51.1 & 38.8 & 47.1 & NA & 36.00 & 53.30 & 53.20 & 48.10 & 48.70 & NA & 46.80 & 48.50 \\
\hline B. Faso & 38.86 & 16.64 & 47.54 & NA & 48.77 & 40.16 & 40.13 & 48.40 & 48.83 & NA & 47.55 & 36.18 \\
\hline I. Coast & 46.89 & 29.66 & 44.65 & NA & 36.92 & 43.43 & 45.36 & 43.78 & 41.86 & NA & 44.75 & 46.92 \\
\hline G. Bissau & 38.91 & 26.31 & 45.34 & NA & 41.37 & 44.87 & 44.80 & 46.86 & 48.68 & NA & 45.05 & 38.27 \\
\hline Mali & 23.51 & 3.09 & 32.53 & 12.76 & 39.83 & 22.93 & 22.85 & 33.14 & 33.58 & 31.50 & 32.38 & 21.34 \\
\hline Niger & 25.00 & 10.44 & 34.84 & 17.21 & 36.93 & 29.53 & 29.39 & 36.04 & 26.99 & 34.16 & 34.84 & 22.72 \\
\hline Senegal & 46.00 & 53.14 & 53.31 & NA & 40.90 & 58.65 & 59.01 & 53.81 & 53.71 & NA & 53.18 & 46.95 \\
\hline Togo & 10.76 & 1.73 & 13.49 & 7.64 & 14.55 & 20.99 & 10.91 & 14.85 & 15.52 & 10.46 & 13.73 & 9.75 \\
\hline Chad & 0.46 & 1.62 & 1.24 & 0.28 & 2.26 & 0.50 & 0.43 & 1.12 & 1.47 & 0.82 & 1.29 & 0.42 \\
\hline
\end{tabular}

Source: Authors' elaboration.

The information of the Copulas estimated for the countries with flexible exchange rate regimes are exposed in the Table 8 . We can observe that for the monthly subsample with one lag $(a(-1))$, the Clayton Copula was more indicated to the CPI observed in Nigeria and Seychelles. Otherwise, the Frank Copula registered the best fit for Ghana and South Africa. In addition, the AMH, the $t$-Student and the Hustler-Reiss Copulas were the best adjustments to modeling the CPI relations of Malawi, Mauritius and Rwanda, respectively. For the quarterly subsample (b), there is the predominance of the Clayton Copula (Rwanda, Nigeria and Seychelles), followed by the $t$-Student Copula, the Hustler-Reiss (South Africa) and the Frank Copula (Ghana). The Clayton Copula also provide the best fit for the annualized data (c). After the estimation of the models, their specification was verified, 
in order to avoid wrong conclusions regarding the relations of dependence of the studied CPI stochastic processes.

Table 8. Log-likelihood of estimated Copulas for the countries with flexible regimes

\begin{tabular}{|c|c|c|c|c|c|c|c|c|c|c|c|c|}
\hline$\stackrel{尺}{\stackrel{\Xi}{E}}$ & 胥 & 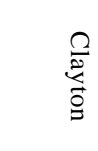 & 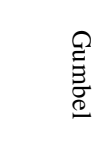 & 3 & $\ddot{\circ}$ & & 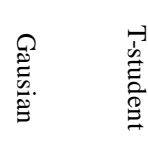 & 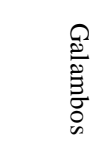 & 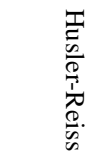 & & 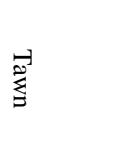 & 車 \\
\hline \multicolumn{13}{|c|}{ (a(-1)) One Lag Sample } \\
\hline Rwanda & 0.29 & 0.31 & 0.20 & 0.24 & 0.27 & 0.12 & 0.10 & 0.35 & 0.38 & 0.17 & 0.23 & 0.30 \\
\hline Ghana & 6.13 & 2.48 & 2.14 & 5.67 & 0.76 & 4.16 & 4.10 & 2.36 & 2.40 & 1.51 & 2.19 & 5.82 \\
\hline Malawi & 5.41 & NA & NA & 6.05 & NA & 4.89 & 4.82 & NA & NA & NA & NA & 5.05 \\
\hline South Africa & 5.05 & 4.11 & 4.97 & 4.60 & 3.72 & 5.42 & 5.43 & 4.68 & 4.55 & 5.03 & 4.88 & 5.08 \\
\hline Nigeria & 3.80 & 0.99 & 1.69 & 3.59 & 0.99 & 2.67 & 2.61 & 2.07 & 2.18 & 0.85 & 1.80 & 3.57 \\
\hline Mauritius & 0.02 & 0.25 & NA & 0.02 & $\mathrm{NA}$ & 0.04 & 0.00 & NA & NA & NA & NA & 0.02 \\
\hline Seychelles & 0.13 & 0.35 & NA & 0.11 & $\mathrm{NA}$ & 0.14 & 0.09 & NA & NA & NA & NA & 0.12 \\
\hline \multicolumn{13}{|c|}{ (b) Quarterly Sample } \\
\hline Rwanda & 0.44 & 0.21 & 0.72 & 0.42 & 0.75 & 0.77 & 0.74 & 0.96 & 1.02 & 0.30 & 0.81 & 0.39 \\
\hline Ghana & 1.47 & 0.00 & 0.96 & 1.10 & 1.00 & 0.87 & 0.85 & 1.19 & 1.28 & 0.52 & 1.01 & 1.42 \\
\hline Malawi & 0.22 & 0.09 & NA & 0.36 & NA & 0.18 & 1.35 & NA & NA & NA & NA & 0.26 \\
\hline South Africa & 2.63 & NA & NA & NA & NA & 3.74 & 3.76 & NA & NA & NA & NA & 2.74 \\
\hline Nigeria & 0.17 & 0.21 & 0.29 & 0.12 & 0.49 & 0.33 & 0.31 & 0.63 & 0.74 & NA & 0.41 & 0.15 \\
\hline Mauritius & 0.01 & 0.03 & NA & 0.01 & NA & 0.01 & 0.00 & 0.00 & 0.00 & NA & NA & 0.00 \\
\hline Seychelles & 0.03 & 0.30 & NA & 0.02 & $\mathrm{NA}$ & 0.05 & 0.05 & NA & NA & NA & NA & 0.03 \\
\hline \multicolumn{13}{|c|}{ (c) Annualized Sample } \\
\hline Rwanda & 10.81 & 6.24 & 9.05 & 10.61 & 6.81 & 10.59 & 10.51 & 9.71 & 9.86 & 7.22 & 9.27 & 9.65 \\
\hline Ghana & 1.94 & 20.82 & NA & 1.31 & 2.20 & 2.16 & NA & NA & NA & NA & NA & 1.86 \\
\hline Malawi & 32.37 & 46.26 & 32.63 & NA & 20.26 & 38.96 & 42.13 & 31.31 & 29.19 & 33.28 & 32.86 & 36.15 \\
\hline South Africa & 5.05 & NA & NA & NA & NA & 5.07 & 5.10 & NA & NA & NA & NA & 4.80 \\
\hline Nigeria & 0.03 & 3.79 & NA & 0.01 & NA & 0.56 & 0.60 & NA & NA & NA & 4.69 & 0.02 \\
\hline Mauritius & 1.97 & 0.50 & 0.01 & 2.29 & $\mathrm{NA}$ & 1.17 & 1.03 & 0.25 & 0.33 & NA & 0.07 & 1.67 \\
\hline Seychelles & 1.61 & 0.35 & 1.70 & 1.05 & 2.32 & 1.02 & 0.98 & 1.77 & 1.80 & 1.47 & 1.69 & 1.53 \\
\hline
\end{tabular}

Source: Authors' elaboration.

The goodness-of-fit tests are illustrated in the Table 9. They reveal that among the 36 Copulas estimated for the countries which adopted the fixed exchange rate regimes, only for 3 of them we rejected the null hypothesis, i.e., that the chosen Copula was appropriate to modeling the dependence relations, considering the significance level of $1 \%$. Among the estimations in which the rejection of the null hypothesis occurred, there are the cases of Niger (quarterly subsample (b)), Mali and Chad, both for the annualized subsample (c). 
Table 9. Goodness-of-fit test of the estimated Copulas

\begin{tabular}{|c|c|c|c|c|}
\hline & Country & $(\mathrm{a}(-1))$ One lag & (b) Quarterly & Annualized Regime \\
\hline \multicolumn{5}{|c|}{ Fixed Regime } \\
\hline C. Verde & & 0.542 & 0.659 & 0.333 \\
\hline S. T. Principe & & 0.053 & 0.037 & 0.035 \\
\hline Benin & & 0.889 & 0.015 & 0.020 \\
\hline B. Faso & & 0.022 & 0.031 & \\
\hline I. Coast & & 0.153 & 0.015 & 1.900 \\
\hline G. Bissau & & 0.015 & 0.039 & 0.600 \\
\hline Mali & & 0.021 & 0.040 & $0.630 *$ \\
\hline Niger & & 0.022 & $0.052 *$ & 0.500 \\
\hline Senegal & & 0.274 & 0.076 & 0.710 \\
\hline Togo & & 0.016 & 0.057 & 0.290 \\
\hline Chad & & 0.022 & 0.050 & $0.091 *$ \\
\hline \multicolumn{5}{|c|}{ Flexible Regime } \\
\hline Rwanda & & 0.031 & 0.025 & $0.071^{*}$ \\
\hline Ghana & & 0.027 & 0.031 & 0.410 \\
\hline Malawi & & 0.390 & 0.067 & 0.160 \\
\hline South Africa & & $0.071^{*}$ & 0.360 & $1.000 * *$ \\
\hline Nigeria & & 0.013 & 0.762 & $0.350 *$ \\
\hline Mauritius & & 0.110 & 0.480 & $0.045^{* *}$ \\
\hline Seychelles & & 0.027 & 0.413 & 0.140 \\
\hline
\end{tabular}

Note: $* 1 \%$ of significance; $* * 5 \%$ of significance; $* * * 10 \%$ of significance.

Source: Authors' elaboration.

For the estimation of Copula for the countries with flexible exchange regimes, the results demonstrate that among the 21 Copulas estimated, only for 5 of them we rejected the null hypothesis that the chosen Copula was the appropriate to modeling the relation of dependence, considering the significance level of $5 \%$. Among them, there are South Africa, for monthly frequency with one lag (a(-1)), Rwanda, South Africa, Nigeria and Mauritius, all of them with annualized frequency (c). Based on the chosen Copulas, the dependence structures described in the Table 3 were estimated and their results will be illustrated in the Table 10 and Table 11 . 
Table 10. Estimated dependence for the countries with fixed regimes

\begin{tabular}{|c|c|c|c|c|}
\hline Country & Kendall's Tau & Spearman's Rho & Lower Tail Index & Upper Tail Index \\
\hline \multicolumn{5}{|c|}{ (a(-1)) One Lag Sample } \\
\hline C. Verde & -0.107 & -0.159 & 0.000 & 0.000 \\
\hline S. T. Principe & 0.084 & 0.126 & 0.000 & 0.109 \\
\hline Benin & 0.265 & 0.390 & 0.000 & 0.000 \\
\hline B. Faso & 0.168 & 0.251 & 0.000 & 0.000 \\
\hline I. Coast & 0.147 & 0.219 & 0.000 & 0.189 \\
\hline G. Bissau & 0.087 & 0.131 & 0.000 & 0.000 \\
\hline Mali & 0.056 & 0.084 & 0.000 & 0.000 \\
\hline Niger & 0.141 & 0.210 & 0.000 & 0.000 \\
\hline Senegal & -0.129 & -0.193 & 0.000 & 0.000 \\
\hline Togo & 0.185 & 0.275 & 0.000 & 0.000 \\
\hline Chad & 0.094 & 0.141 & 0.000 & 0.000 \\
\hline \multicolumn{5}{|c|}{ (b) Quarterly Sample } \\
\hline C. Verde & 0.086 & 0.129 & 0.000 & 0.115 \\
\hline S. T. Principe & 0.438 & 0.610 & 0.641 & 0.000 \\
\hline Benin & 0.332 & 0.482 & 0.000 & 0.000 \\
\hline B. Faso & 0.285 & 0.414 & 0.000 & 0.351 \\
\hline I. Coast & 0.203 & 0.300 & 0.000 & 0.000 \\
\hline G. Bissau & 0.084 & 0.125 & 0.154 & 0.154 \\
\hline Mali & 0.073 & 0.109 & 0.000 & 0.095 \\
\hline Niger & 0.143 & 0.214 & 0.126 & 0.000 \\
\hline Senegal & -0.163 & -0.24 & 0.110 & 0.110 \\
\hline Togo & 0.159 & 0.236 & 0.000 & 0.203 \\
\hline Chad & -0.083 & -0.124 & 0.000 & 0.000 \\
\hline \multicolumn{5}{|c|}{ (c) Annualized Sample } \\
\hline C. Verde & 0.244 & 0.337 & 0.000 & 0.304 \\
\hline S. T. Principe & 0.568 & 0.769 & 0.000 & 0.000 \\
\hline Benin & 0.450 & 0.632 & 0.000 & 0.000 \\
\hline B. Faso & 0.411 & 0.580 & 0.000 & 0.580 \\
\hline I. Coast & 0.421 & 0.587 & 0.000 & 0.000 \\
\hline G. Bissau & 0.477 & 0.660 & 0.000 & 0.556 \\
\hline Mali & 0.330 & - & 0.000 & 0.557 \\
\hline Niger & 0.356 & 0.510 & 0.000 & 0.430 \\
\hline Senegal & 0.462 & 0.646 & 0.145 & 0.145 \\
\hline Togo & 0.228 & 0.335 & 0.000 & 0.286 \\
\hline Chad & 0.121 & - & 0.000 & 0.253 \\
\hline
\end{tabular}

Source: Authors' elaboration.

In the Table 10 we can notice that for the monthly frequency subsample with one lag $(\mathrm{a}(-1))$, the results suggest a small dependence between the CPI of the analyzed countries and the CPI of countries from the EMZ. In some cases, such as Cape Verde and Senegal, this measure is negative, and this goes against the priori expectations of this research. The countries which demonstrated the higher dependence were Benin, Togo, Burkina Faso and Ivory Coast. However, when the Copulas are estimated using the quarterly subsample (b), an increase on the level of dependence between the CPI of these countries and the EMZ countries was observed.

On the other hand, an increase on the level of dependence between the CPI of the annualized subsample (c) was observed. Sao Tome and Principe, Guinea-Bissau, Senegal, Benin, Ivory Coast and Burkina Faso were the countries which presented the most expressive measures, and all of them were positive. Chad was the country with the lowest level of dependence among the studied countries. Two factors may explain these results $(i)$ the fact that the CPI is measured only in N'Djamena, the capital of the country, and (ii) due to its constant internal political instabilities, which places the gains obtained by the adoption of a fixed exchange rate at risk. The Tail Index, in contrast, indicate that half of the chosen Copulas were asymmetric, for both, quarterly (b) and annualized (c) subsamples. It is possible to observe that Cape Verde, Burkina Faso, Guinea-Bissau, Mali, Senegal and Togo evidenced certain dependence in the superior tail of the distribution, i.e., for the moments of price increases. It could reflect that those countries had inelastic demands for tradable goods coming from the EMZ countries. 
The measures of dependence of the countries with flexible regimes are displayed in the Table 11 .

Table 11. Estimated dependence for the countries with flexible regimes

\begin{tabular}{|c|c|c|c|c|}
\hline Country & Kendall's Tau & Spearman's Rho & Lower Tail Index & Upper Tail Index \\
\hline \multicolumn{5}{|c|}{ (a) Monthly Sample } \\
\hline Rwanda & 0.037 & 0.055 & 0.000 & 0.048 \\
\hline Ghana & 0.162 & 0.241 & 0.000 & 0.000 \\
\hline Malawi & -0.176 & -0.263 & 0.000 & 0.000 \\
\hline South Africa & 0.141 & 0.210 & 0.000 & 0.000 \\
\hline Nigeria & -0.034 & -0.052 & 0.000 & 0.000 \\
\hline Mauritius & 0.152 & 0.227 & 0.000 & 0.000 \\
\hline Seychelles & -0.046 & -0.070 & 0.000 & 0.000 \\
\hline \multicolumn{5}{|c|}{ (b) Quarterly Sample } \\
\hline Rwanda & 0.140 & 0.210 & 0.000 & 0.000 \\
\hline Ghana & 0.116 & 0.174 & 0.000 & 0.000 \\
\hline Malawi & -0.230 & -0.35 & 0.000 & 0.000 \\
\hline South Africa & 0.111 & 0.165 & 0.000 & 0.143 \\
\hline Nigeria & -0.029 & -0.043 & 0.000 & 0.000 \\
\hline Mauritius & -0.068 & -0.101 & 0.000 & 0.000 \\
\hline Sevchelles & -0.098 & -0.146 & 0.000 & 0.000 \\
\hline \multicolumn{5}{|c|}{ (c) Annualized Sample } \\
\hline Rwanda & 0.209 & 0.311 & 0.000 & 0.000 \\
\hline Ghana & -0.223 & -0.324 & 0.000 & 0.000 \\
\hline Malawi & -0.165 & -0.245 & 0.000 & 0.000 \\
\hline South Africa & 0.115 & 0.171 & 0.000 & 0.153 \\
\hline Nigeria & 0.108 & 0.162 & 0.000 & 0.000 \\
\hline Mauritius & 0.364 & 0.519 & 0.546 & 0.000 \\
\hline Seychelles & 0.132 & - & 0.000 & 0.272 \\
\hline
\end{tabular}

Source: Authors'elaboration.

The results for the monthly frequency subsample with one lag $(\mathrm{a}(-1))$ and the quarterly frequency $(\mathrm{b})$ indicated that for Malawi, Nigeria and Seychelles, the dependence relation is negative, even though the magnitude is small, except for Malawis case, that registered a significant negative dependence relation with the CPI of the EMZ countries. For the annualized frequency subsample (c), the negative measures of dependence were observed in Ghana and Malawi. We can highlight Rwanda, South Africa and Mauritius for presenting the higher levels of dependence with the CPI with regard to the EMZ countries.

We emphasize that these empirical evidences could not be obtained using other models, such the Vector Autoregressive models (VAR), Vector Error-Correction (VEC), for example, because they establish linear relations, which the estimated parameters are conditioned to the average, else the need of priori knowledge to modeling the systems and relations between the studied variables. And, above all, from the statistical point of view, its estimators require the normal distributions of the residues. In general, we observed that in most cases, for the countries with flexible regimes, there is a small relation of dependence among the CPI. Consequently, we tried to relate the estimated parameters with the Degree of Economic Opening (DEO) of the countries, in order to obtain more information, as denoted in Figure 1.
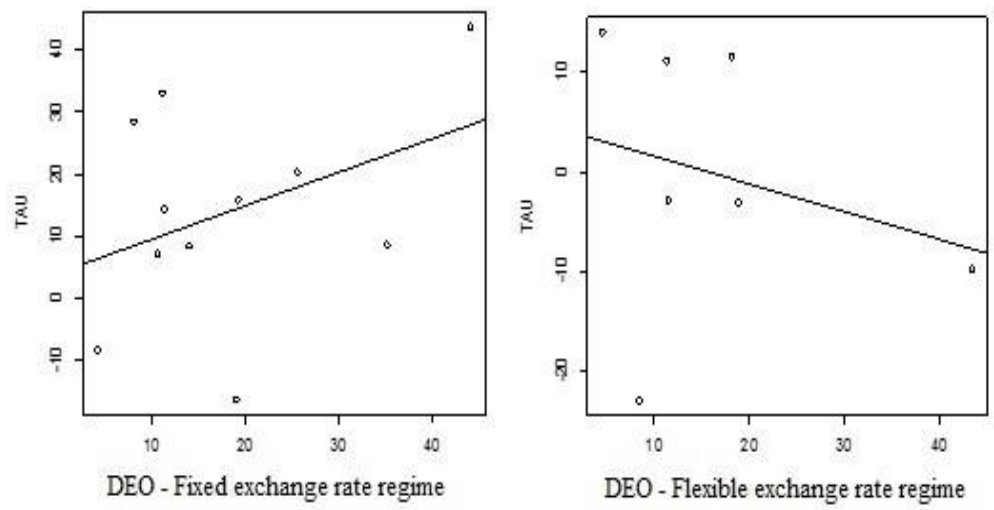

Figure 1. Dispersion between the Degree of Economic Opening (DEO) and the Kendall's Tau

Source: Authors'elaboration.

In the Figure 1 we observe the dispersion between the DEO of the studied countries related to the EMZ, and the Kendall's Tau, estimated by using the quarterly subsample (b). The GAE of each country is given by the average 
ratio between trade (the sums of all of its importations and exportations of goods and services) with the EMZ countries, divided by the GDP of each sampled country, during the period of 1999 and 2014. The countries which adopted fixed exchange rate regimes pointed to higher positive relations between the CPI dependence and the GAE, then the countries which adopted flexible regimes.

Furthermore, the data indicated that there were no significant differences regarding the GAE between the exchange regimes in the studied countries. For the fixed regimes, the average of the GAE was $18.5 \%$, while for the countries with flexible regimes, it was $16.6 \%$. Nonetheless, the same relation was not verified when the Kendall's Tau is considered. Also, we did not observe a Kendall's Tau above 0.2 among countries with flexible exchange rate regimes, when we used the quarterly subsample (b) as data. For the annualized frequency subsample (c), no country obtained estimations of dependence above the registered average in the countries which adopted fixed exchange regimes.

\section{Key Findings and Discussion}

The information produced in our research lead to some key findings, which must be carefully analyzed. First, it is difficult to establish a linear relation among the CPI of the studied countries, according to the equation (2). Secondly, the methodology of Copulas lead to some advances, as well, as the efforts of (i) estimate various functional forms of Copulas to fit our data, and (ii) control the estimations by sample design changing and (iii) the results by the exchange rate regimes adopted by each studied country.

For the general case, the estimated Copulas presented better fits to the annualized subsamples comprehended during the accords to countries which adopted fixed exchange rate regimes. These countries, for instance, revealed in average, positive significant dependences with regard the CPI observed in the EMZ countries. In this sense, as pointed out, the literature, from pioneer studies, such as Friedman, (1953), to more recent empirical researches, such as Husain, Mody and Rogoff (2005) and Toulaboe and Terry (2013), some small open economies with a relative degree of openness could benefit from fixed exchange rate regimes with regard their main trade partners. However, when adopting the fixed exchange rate regime, these types of small developing economies, as exposed by Jalles (2010), tend to import the inflation of its essential trade partners.

On the other hand, considering the costs of the inflation control, we report that for the reduced dependencies between the CPI stochastic processes, it is possible that a change from the fixed regime linked to the Euro to a flexible regime, could improve the efficiency of the economic policies. The DEO and the Kendall's Tau estimations possibly express that for the first group of countries there is a positive relation among trading and imported inflation. Otherwise, for the countries which made option for the flexible exchange rate regimes, the relation aforementioned is considerably smaller and negative.

Additionally, the estimations displayed that there seems to be other factors that influence the CPI dynamics, and, consequently, their impact on the most appropriate policy path for each SSA studied country. We also highlight that these results could improve with the using of the pairs of time series data, regarding the CPI observed in each of the partners of the SSA countries, besides signaling for the existence of other possible relevant new trading partners, as China, for example. Hence, the exchange rate policy is fundamental for the coordination of positive results for the emerging countries, as well, as the selected countries for this study.

As stated to Appleyard, Field and Cobb (2009) one of the intrinsic characteristics of the countries in development is that their economic systems are more rigid and less stimulated in the face of price changes, at least, in the short term. Therefore, the microeconomic aspects, as well as those associated to the domestic policies, have a significant impact in the dynamic of the prices. This makes the decisions about the best exchange rate regime go through a theoretical and empirical analysis, also considering the small dependence of the CPI of the studied economies related to the Euro.

Ensuring the stability of the prices is the main objective of the monetary authorities, facing the costs caused to the economy by high CPI. This fact has stimulated studies about their determinants and some of them incorporate the imported inflation costs, by observing how the variation in the external prices affect the domestic price level of various economies, process named imported inflation, as already mentioned.

A limitation of those kind of research is due the absence of data for the African countries. Much of statistic methods require databases with a minimum of observations, because most of those estimators' precision are asymptotic. This way, modeling specific empirical evidence for the developing countries, especially of the SSA, is difficult and another studies in literature are rare. This decision is linked to another limitation of this research, which emerge of the fact that we do not consider the case of time-varying dependence estimators. To use such techniques, in most part of the cases it is necessary larger databases and with higher frequencies, i.e., with more 
observations, to correcting specification and identification of the models.

\section{Conclusion}

In sense of provide some empirical evidence of the CPI relations, our contribution was to estimate different measures of Copulas, controlling the results by the exchange rate regimes and trade agreements, for each of the studied country, considering the monthly, quarterly and annualized frequencies of the data. In sense of estimate robust measures, we also controlled the estimations by using 1 lag in the transmission of imported inflation. As exposed, it is very difficult to obtain well-structured data from African countries, which definitively could improve the presence of researches about economy policies based onempirical evidence for the use of the policy makers.

We observed that for the countries with flexible regimes, the dependence relation is reduced. Comparatively, we noted that the countries with a fixed regimes pointed to higher relation of dependence. This may suggest that these countries are in the right direction regarding the exchange rate policy, and the reaction functions of the monetary authorities must consider the external prices and the monetary policies in the EMZ. Specifically, Sao Tome and Principe, Guinea-Bissau, Senegal, Benin, Ivory Coast and Burkina Faso reveal more expressive relation of dependence among the analyzed countries. Chad, for instance, presented the low relation of dependence, which could be associated with its institutional instabilities. Burkina Faso, Guinea-Bissau, Mali, Niger, Cape Verde, Togo and Senegal, on the other hand, dependence was registered in the superior tail of the distribution, i.e., for the periods of European prices increasing. Apparently, this means that those countries had inelastic demands for tradable goods coming from the EMZ countries.

Alternatively, even using more robust statistic estimators to capture the relations between the CPI of the studied countries, the Copulas which provide the best fits for each case, also suggest that are different drivers of the supply side and of the demand side for the studied economies, which were possibly could be captured through the CPI time series patterns. Finally, the results indicated that in addition to the external inflation, other factors may help in the decision of which exchange rate regime is the most appropriate for each of studied countries. This way, our results are in line with the last studied that pointed out that there is no rigid path to development. It increases the possibilities for the policy makers, regarding the variables to be considered in the decision-making processes.

We think fixed exchange rate regimes for small economies in development had many benefits, nonetheless also may create vulnerabilities to crisis and external events, because in average, they could not afford high reserves in foreign currencies, as strategy policy adopted by other emerging countries. This has been observed in some developing economies, that after successive crisis during the 1990's, had increased their international reserves to be less vulnerable to short-term instabilities. This is just one example of how is important the development of the institutions of the African countries.

Nevertheless, we reiterate that the choice of which exchange rate regime to adopt is very important for the SSA developing countries. Also, it was possible to observe the importance of the empirical evidence on the decision making processes, which could be considered in other regions of similar economies, such as the countries of the LA, for example. Among the similarities, for the countries of the LA there is also the intention of creating a more advanced commercial and financial synergy, especially with the regard to the Mercosur participants. Thus, we believe that new researches can continue to pursue other empirical evidences about the SSA countries, since the African continent has great economic potential. Also, the Copulas model could be used to estimate the relations of dependence in the countries of LA or other blocs, and provide similar empirical evidence as produce by this study.

\section{References}

Antunes, A. R. (2015). Co-movement of revisions in short-and long-term inflation expectations. Banco de Portugal Economic Studies, 1(1), 1-19.

Appleyard, D. R., Field, A. J., \& Cobb, S. L. (2009). International economics. ( $7^{\text {th }}$ ed.) New York: McGraw-Hill.

Araújo, P. D. (2015). Calculating welfare costs of inflation in a search model with preference heterogeneity: a calibration exercise. Bulletin of Economic Research, 67, 14-29. https://doi.org/10.1111/j.1467-8586.2012.00471.x

Blavy, R. (2004). Inflation and monetary pass-through in Guinea. IMF Working Papers, WP/04/223, International Monetary Fund. https://doi.org/10.5089/9781451875324.001

Carmignani, F., Colombo, E., \& Tirelli, P. (2008). Exploring different views of exchange rate regime choice. Journal of International Money and Finance, 27(7), 1177-1197. https://doi.org/10.1016/j.jimonfin.2008.06.004

Carvalho, J., Massala, L., \& Santos, M. (2012). Determinantes da inflação em Angola. Working Discussion 
Paper, Banco Nacional de Angola.

Chiu, E. M., \& Willett, T. D. (2009). The interactions of strength of governments and alternative exchange rate regimes in avoiding currency crises. International Studies Quarterly, 53(4), 1001-1025. https://doi.org/10.1111/j.1468-2478.2009.00566.x

Delgado, J., \& Santos, O. (2006). Determinantes da inflação em Cabo Verde. Working Papers, 4/2006, Banco de Cabo Verde.

Dornbusch, R. (2001). Fewer monies, better monies. The American Economic Review, 91(2), 238-242. https://doi.org/10.1257/aer.91.2.238

Durevall, D., \& Sj, B. (2012). The dynamics of inflation in Ethiopia and Kenya. IMF Working Papers, WP/12/151, International Monetary Fund.

Embrechts, P., McNeil, A., \& Straumann, D. (2002). Correlation and dependence in risk management: properties and pitfalls. Risk management: value at risk and beyond, 176-223, Cambridge University Press.

Fischer, S. (1981). Towards an understanding of the costs of inflation: Carnegie-Rochester Conference Series on Public Policy, 5-41. North-Holland.

Fornaro, L. (2015). Financial crises and exchange rate policy. Journal of International Economics, 95(2), 202-215. https://doi.org/10.1016/j.jinteco.2014.11.009

Friedman, L. (1953). The case for flexible exchange rate. I. Friedman, editor, Essays in Positive Economics, 157-203. University of Chicago Press.

Gali, J., \& Monacelli, T. (2005). Monetary policy and exchange rate volatility in a small open economy. The Review of Economic Studies, 72(3), 707-734. https://doi.org/10.1111/j.1467-937X.2005.00349.x

Genest, C., \& Remillard, B. (2004). Test of independence and randomness based on the empirical Copula process. Test, 13(2), 335-369. https://doi.org/10.1007/BF02595777

Genest, C., Remillard, B., \& Beaudoin, D. (2009). Goodness-of-fit tests for Copulas: Areview and a power study. Insurance: Mathematics and economics, 24(2), 199-213. https://doi.org/10.1016/j.insmatheco.2007.10.005

Guerron-Quintana, P. A. (2011). The implications of inflation in an estimated new Keynesian model. Journal of Economic Dynamics and Control, 35(6), 947-962. https://doi.org/10.1016/j.jedc.2011.01.008

Hanson, J. (1985). Inflation and some imported input prices in some inflationary Latin American economies. Journal of Development Economics, 18, 395-410. https://doi.org/10.1016/0304-3878(85)90064-1

Harberger, A. (1963). The dynamics inflation in Chile. Measurement in Economics. Stanford University Press.

Husain, A. M., Mody, A., \& Rogoff, K. S. (2005). Exchange rate regime durability and performance in developing versus advanced economies. Journal of Monetary Economics, 52, 35-64. https://doi.org/10.1016/j.jmoneco.2004.07.001

Jalles, J. T. (2010). Inter-country trade dependence and inflation transmission mechanisms: the case of a small open African economy. International Journal of Development Issues, 9(3), 3-198.

Kim, B. Y. (2008). Modeling inflation in Poland: a structural cointegration approach. Eastern European Economics, 46(6), 60-69. https://doi.org/10.2753/EEE0012-8775460603

Kinda, T. (2011). Modeling inflation in Chad. IMF Working Papers, WP/11/57, International Monetary Fund.

Klein, N., \& Kyei, A. (2009). Understanding inflation inertia in Angola. IMF Working Papers, WP/09/98, International Monetary Fund. https://doi.org/10.5089/9781455221011.001

McCallum, B., \& Nelson, E. (2000). Monetary policy for an open economy: an alternative framework with optimizing agents and sticky prices. Oxford Review of Economic Policy, 16(4), 74-91. https://doi.org/10.1093/oxrep/16.4.74

Moreira, R., Chaiboonsri, C., \& Chaitip, P. (2013). Weak dependence between the Brazilian consumer inflation and expected inflation: non-linear and Copulas methods and a note on the central bank's credibility. International Journal of Monetary Economics and Finance, 6(1), 40-54. https://doi.org/10.1504/JJMEF.2013.055701

Moriyama, K. (2008). Investigating inflation dynamics in Sudan. IMF Working Papers, WP 08/189, International Monetary Fund. https://doi.org/10.5089/9781451870473.001

Ndanshau, M. (2010). Money and other determinants of inflation: the case of Tanzania. Indian Journal of 
Economics and Business, 9(3), 503-545.

Nelsen, R. B. (2006). An introduction to Copulas. $\left(2^{\text {nd }}\right.$ ed.) New York: Springer-Verlag.

Obstfeld, M., \& Rogoff, K. (1995). The mirage of fixed exchange rates. Journal of Economic Perspectives, 9(4), 73-96. https://doi.org/10.1257/jep.9.4.73

Oliveira, J. C. T., Silva, M. M., \& Lima, R. O. (2014). The dependence between Cape-Verdean and Portuguese inflation: a copula approach. Revista Brasileira de Economia de Empresas, 14(1), 51-66.

Olubusoye, O., \& Oyaromade, R. (2008). Modeling the inflation process in Nigeria. AERC Research Paper, 182, African Economic Research Consortium.

Poirson, H. (2001). How do countries choose their exchange rate regime? IMF Working Papers, WP/01/4, International Monetary Fund.

Quirk, P. J. (1996). Exchange rate regimes as inflation anchors. Finance \& Development, 3(1), 42-45.

Rodriguez, C. M. (2016). Economic and political determinants of exchange rate regimes: the case of Latin America. International Economics, 147(3), 1-26. https://doi.org/10.1016/j.inteco.2016.03.001

Saleem, K., Collan, M., Ahmed, S., \& Gyasi, A. K. (2014). Market integration, return and volatility dynamics: empirical evidence from African stock markets. International Business Research, 7(9), 30-44. https://doi.org/10.5539/ibr.v7n9p30

Sissoko, D., \& Dibooglu, S. (2006). The exchange rate system and macroeconomic fluctuations in Sub-Saharan Africa. Economic Systems, 30(2), 141-156. https://doi.org/10.1016/j.ecosys.2015.02.002

Sklar, A. (1959). Fonctions de repartition a n dimensions et leurs marges. Publications de L'Institut de Statistique de L'Universit de Paris, 8, 229-231.

Smal, M. M. (1998). The cost of inflation. South African Reserve Bank Quarterly Bulletin, 34, 33-45.

Toe, M. D. (2011). Modeles de prevision de l'inflation dans les pays de l'UEMOA. BCEAO, Document d'Etude et de Recherche DER/11/03.

Toe, M. D., \& Lien, M. H. (2007). Lien entre la masse monetaire et l'inflation dans les pays de l'UEMOA. BCEAO, Document d'Etude et de Recherche. DER/07/02.

Toulaboe, D., \& Terry, R. (2013). Exchange rate regime: does it matter for inflation? Journal of Applied Business and Economics, 14(1), 56-71.

Zhang, H., \& Jiao, F. (2012). Factor copula models and their application in studying the dependence of the exchange rate returns. International Business Research, 5(2), 3-12. https://doi.org/10.5539/ibr.v5n2p3 


\section{Appendix A}

Table 12. Descriptive statistics of the variables of the countries with fixed regimes

\begin{tabular}{|c|c|c|c|c|c|c|c|c|c|}
\hline & Average & Median & Min. & Max. & Standard & Skewness & Kurtosis & Jarque Bera & N. Obs \\
\hline \multicolumn{10}{|c|}{ (a) Monthly Sample } \\
\hline EMZ & 0.11 & 0.12 & -1.55 & 1.35 & 0.54 & -0.32 & 3.86 & 3.45 & 72 \\
\hline WAEMU & 0.15 & 0.17 & -1.55 & 1.35 & 0.40 & -0.54 & 5.40 & $58.91 *$ & 204 \\
\hline Benin & 0.21 & 0.21 & -2.62 & 4.97 & 1.19 & 0.62 & 4.47 & $31.70 *$ & 204 \\
\hline B. Faso & 0.19 & 0.10 & -2.73 & 4.18 & 1.20 & 0.39 & 3.56 & $7.94 * *$ & 204 \\
\hline C. Verde & 0.15 & 0.16 & -2.16 & 3.17 & 0.75 & 0.37 & 5.18 & $45.09 *$ & 204 \\
\hline Chad & 0.30 & 0.39 & -3.83 & 8.78 & 1.79 & 0.82 & 6.96 & $80.92 *$ & 107 \\
\hline I. Coast & 0.22 & 0.14 & -2.92 & 6.25 & 0.88 & 2.21 & 17.67 & $1995.39 *$ & 204 \\
\hline G. Bissau & 0.12 & 0.13 & -2.43 & 3.16 & 0.97 & 0.00 & 3.54 & 2.00 & 162 \\
\hline Mali & 0.19 & 0.17 & -2.59 & 4.62 & 1.11 & 0.27 & 3.93 & $9.79 *$ & 204 \\
\hline Niger & 0.17 & 0.00 & -3.64 & 5.36 & 1.25 & 0.77 & 4.88 & $50.07 *$ & 204 \\
\hline S. T. Principe & 0.72 & 0.50 & -0.30 & 2.40 & 0.57 & 1.26 & 4.14 & $22.87^{*}$ & 72 \\
\hline Senegal & 0.13 & 0.00 & -3.17 & 2.85 & 0.91 & -0.11 & 3.56 & 3.00 & 204 \\
\hline Togo & 0.22 & 0.18 & -3.21 & 4.25 & 1.15 & 0.01 & 4.08 & $9.88 *$ & 204 \\
\hline \multicolumn{10}{|c|}{ (b) Quarterly Sample } \\
\hline EMZ & 0.35 & 0.19 & -0.87 & 1.60 & 0.70 & 0.25 & 1.91 & 1.43 & 24 \\
\hline WAEMU & 0.45 & 0.39 & -0.87 & 1.64 & 0.57 & 0.13 & 2.56 & 0.76 & 68 \\
\hline Benin & 0.65 & 0.65 & -2.94 & 4.65 & 1.43 & 0.22 & 3.56 & 1.45 & 68 \\
\hline B. Faso & 0.53 & 0.61 & -3.14 & 5.10 & 1.74 & 0.17 & 2.60 & 0.77 & 68 \\
\hline C. Verde & 0.46 & 0.45 & -2.58 & 3.63 & 1.27 & 0.25 & 2.94 & 0.72 & 68 \\
\hline Chad & 0.90 & 0.81 & -4.66 & 7.14 & 3.02 & 0.18 & 2.68 & 0.34 & 35 \\
\hline I. Coast & 0.65 & 0.62 & -2.34 & 6.76 & 1.43 & 1.10 & 6.78 & $54.31 *$ & 68 \\
\hline G. Bissau & 0.42 & 0.55 & -4.67 & 3.03 & 1.71 & -0.78 & 3.36 & 5.66 & 53 \\
\hline Mali & 0.53 & 0.77 & -4.51 & 5.23 & 2.21 & -0.19 & 2.53 & 1.03 & 68 \\
\hline Niger & 0.51 & 0.61 & -4.38 & 5.20 & 2.09 & 0.04 & 2.42 & 0.96 & 68 \\
\hline S. T. Principe & 0.72 & 0.62 & 0.17 & 1.63 & 0.42 & 0.67 & 2.43 & 2.10 & 24 \\
\hline Senegal & 0.41 & 0.09 & -3.77 & 3.76 & 1.56 & -0.06 & 2.72 & 0.25 & 68 \\
\hline Togo & 0.67 & 0.68 & -3.72 & 4.50 & 1.70 & 0.02 & 3.14 & 0.06 & 68 \\
\hline \multicolumn{10}{|c|}{ (c) Annualized Sample } \\
\hline EMZ & 1.44 & 1.59 & -0.61 & 3.03 & 1.03 & -0.13 & 1.66 & $5.56^{* *}$ & 72 \\
\hline WAEMU & 1.81 & 2.00 & -0.64 & 4.05 & 0.93 & -0.52 & 2.99 & $9.14 *$ & 204 \\
\hline Benin & 2.60 & 2.25 & -3.31 & 13.53 & 2.94 & 0.60 & 3.29 & $13.03^{*}$ & 204 \\
\hline B. Faso & 2.05 & 1.33 & -3.07 & 13.98 & 3.35 & 1.17 & 4.40 & $63.59^{*}$ & 204 \\
\hline C. Verde & 2.07 & 1.98 & -4.22 & 10.22 & 2.95 & 0.19 & 2.42 & 4.13 & 204 \\
\hline Chad & 4.00 & 3.13 & -5.24 & 19.60 & 5.13 & 0.57 & 2.89 & $5.12 * *$ & 95 \\
\hline I. Coast & 2.52 & 2.20 & -3.85 & 9.12 & 2.01 & 0.28 & 3.26 & 3.14 & 204 \\
\hline G. Bissau & 2.03 & 1.97 & -7.24 & 11.30 & 3.24 & 0.14 & 3.62 & 2.83 & 150 \\
\hline Mali & 2.13 & 1.72 & -6.46 & 11.45 & 3.47 & 0.34 & 3.08 & 4.00 & 204 \\
\hline Niger & 1.91 & 1.31 & -4.89 & 13.46 & 3.69 & 1.10 & 4.31 & $55.81^{*}$ & 204 \\
\hline S. T. Principe & 9.80 & 10.10 & 3.96 & 17.40 & 3.58 & 0.24 & 1.93 & 4.14 & 72 \\
\hline Senegal & 1.56 & 1.26 & -4.98 & 7.99 & 2.38 & 0.17 & 3.53 & 3.28 & 204 \\
\hline Togo & 2.50 & 2.09 & -3.77 & 14.11 & 3.17 & 0.69 & 3.80 & $21.71 *$ & 204 \\
\hline
\end{tabular}

Note: $* 1 \%$ of significance; $* * 5 \%$ of significance; $* * * 10 \%$ of significance.

Source: Authors'elaboration. 
Table 13. Descriptive statistics of the variables of the countries with flexible regimes

\begin{tabular}{|c|c|c|c|c|c|c|c|c|c|}
\hline & Average & Median & Min. & Max. & Standard & Skewness & Kurtosis & J. Bera & N. Obs. \\
\hline \multicolumn{10}{|c|}{ (a) Monthly Sample } \\
\hline Ghana & 1.31 & 1.29 & -2.56 & 10.88 & 1.43 & 1.52 & 12.44 & $834.88^{*}$ & 204 \\
\hline Malawi & 1.06 & 0.60 & -9.43 & 11.90 & 3.31 & 0.33 & 2.88 & 3.33 & 179 \\
\hline Mauritius & 0.40 & 0.32 & -2.45 & 3.01 & 0.63 & 0.79 & 7.63 & $203.86^{*}$ & 204 \\
\hline Nigeria & 0.90 & 0.77 & -3.46 & 7.40 & 1.40 & 0.66 & 7.07 & $127.28 *$ & 167 \\
\hline Rwanda & 0.48 & 0.45 & -3.94 & 5.11 & 1.23 & 0.08 & 4.45 & $18.10^{*}$ & 204 \\
\hline Seychelles & 0.58 & 0.24 & -2.33 & 9.04 & 1.40 & 2.82 & 15.88 & 882.03* & 107 \\
\hline South Africa & 0.42 & 0.33 & -1.09 & 1.69 & 0.47 & 0.21 & 3.74 & 5.07 & 167 \\
\hline \multicolumn{10}{|c|}{ (b) Quarterly Sample } \\
\hline Ghana & 3.83 & 3.41 & -1.67 & 10.24 & 2.64 & 0.20 & 2.89 & 0.47 & 68 \\
\hline Malawi & 3.05 & 0.31 & -5.61 & 17.56 & 6.59 & 0.37 & 1.75 & 5.22 & 59 \\
\hline Mauritius & 1.22 & 1.05 & -1.19 & 4.81 & 1.17 & 0.56 & 3.65 & $4.80 * *$ & 68 \\
\hline Nigeria & 2.72 & 2.35 & -4.70 & 10.44 & 2.41 & 0.18 & 5.42 & $13.77 *$ & 55 \\
\hline Rwanda & 1.45 & 1.15 & -3.80 & 7.54 & 2.27 & 0.40 & 3.35 & 2.13 & 68 \\
\hline Seychelles & 2.01 & 0.69 & -2.10 & 12.88 & 3.54 & 1.73 & 5.17 & $24.27 *$ & 35 \\
\hline South Africa & 1.26 & 1.32 & -2.11 & 3.31 & 0.98 & -0.34 & 4.54 & $6.53 * *$ & 55 \\
\hline \multicolumn{10}{|c|}{ (c) Annualized Sample } \\
\hline Ghana & 16.30 & 14.90 & 8.39 & 41.90 & 7.38 & 1.64 & 5.55 & $146.18^{*}$ & 204 \\
\hline Malawi & 14.40 & 12.10 & 3.11 & 38.00 & 7.39 & 0.91 & 3.16 & $23.63^{*}$ & 167 \\
\hline Mauritius & 5.18 & 4.80 & 0.06 & 12.30 & 2.63 & 0.60 & 3.15 & $12.44 *$ & 204 \\
\hline Nigeria & 11.30 & 10.60 & 3.00 & 28.20 & 4.52 & 1.24 & 5.10 & $68.44^{*}$ & 155 \\
\hline Rwanda & 5.45 & 5.77 & -15.70 & 22.50 & 7.16 & -0.53 & 3.69 & $13.72 *$ & 204 \\
\hline Seychelles & 11.00 & 4.00 & -6.00 & 63.00 & 16.34 & 1.56 & 4.31 & $45.85^{*}$ & 95 \\
\hline South Africa & 4.95 & 5.00 & -2.00 & 12.00 & 2.91 & -0.33 & 3.54 & $4.80 * *$ & 155 \\
\hline
\end{tabular}

Note: $* 1 \%$ of significance; $* * 5 \%$ of significance; $* * * 10 \%$ of significance.

Source: Authors' elaboration.

\section{Copyrights}

Copyright for this article is retained by the author(s), with first publication rights granted to the journal.

This is an open-access article distributed under the terms and conditions of the Creative Commons Attribution license (http://creativecommons.org/licenses/by/4.0/). 